\title{
ADAM A.S BUKAN MANUSIA PERTAMA DALAM TAFSIR AL-TAHRIR WA AL-TANWIR KARYA IBNU 'ATSUR (ANALISIS SURAH AL-BAQARAH AYAT 30)
}

Oleh:

\section{Dame Siregar ${ }^{1}$}

\begin{abstract}
Human as a creature created by the Khaliq for several reasons, the theological like to worship Him, pray, away from what he has forbidden and pursue what is commanded. In social language it is to continue to grow and become a useful being. The phrase to be better has certainly been a long process, requiring mental, character, and physical changes. Academically historical studies are always related to phenomena, both phenomena that occur through the something found and a text. Like the findings of fossils or skeletons that are believed to have lived much longer with Adam A.S to Muslim beliefs as the first humans were created.

This is happenedin the interpretation of Ibn 'Atsur in tafsir of al-Tahrir wa alTanwir states that once lived a group of beings who have human likeness in QS, al-baqarah (2): 30 regarding the creation of Adam A.S. in his commentary view there is a name quote that became the first creature created but made the destruction of the earth, instead, it was created the prophet Adam A.S as the most perfect form (innovation).

From this the author goes on to trace further on the history of human creation, and focuses problem on the QS. Al-Baqarah (2): 30, and stands on some important questions, what underlies the interpretation? And what influences Ibn 'Atsur's method of interpretation? And what happened at that time?

The results found that his method to interpretation applied by Ibn 'Atsur is not Stagnant in the sense that he always receives a lot of knowledge from various circles of scientists who are considered worthy to be published, like the opinion of Persian and Greek beliefs concerning the first creature is not Adam AS, of humanity and Jin. Absolutely, this is not a real truth according to Ibn 'Atsur also, seen from the interpreter that is not too elongated in this
\end{abstract}

${ }^{1}$ Penulis adalah Dosen Fakultas Syariah dan Ilmu Hukum IAIN Padangsidimpuan 
matter. But he still put it because it has the value of science that is considered valuable, seen at that time has been found a fossil or frame that is believed to be a human-like creature that has lived very long. This interpretation is also reinforced by the one-time interpreter Muhammad Abduh who states the same way. The conclusion that can be captured by the author is that when it is a science, there is no harm in being included in a work such as tafsir, to be known to everyone and the extension of knowledge.

Keywords: Adam, Human, Knowledge, innovation, method of interpretation

\section{Pendahuluan}

Dalam kehidupan bermasyarakat perlu adanya sebuah jalinan yang sehat. Untuk membangun mindset ini diperlukan akal yang sehat. Berbicara memilki akal sudah barang tentu hanya manusia yang pasti akalnya sehat dan sempurnya diantara makhluk-makhluk lain. Selain kehidupan-kehidupan manusia sudah sangat nyaman dan beradab dirasakan di zaman sekarang. Di sini sangat perlu diketahui tentang sejarah awal mulanya manusia, siapa manusia pertama diciptakan? Bagaimana proses penciptaannya? Untuk apa ia diciptakan? Perlukah ia harus diciptakan? Ini beberapa pertanyaan yang perlu kita pertanyakan di tatanan sosial kehidupan sekarang, jagan sampai kita kepada ketidak pedulian akan sejarah awal mula manusia.

Secara sederhana manusia adalah makhluk sosial ciptaan Tuhan Yang Maha Esa sebagai khalifah dibumi dengan dibekali akal pikiran untuk berkarya dimuka bumi. Manusia memiliki perbedaan baik secara biologis maupun rohani. Jika ditelusuri masalah asal usul diciptakannya manusia pertama dibumi, maka beberapa ulama tafsir masih berbeda pendapat siapakah makhluk pertama dibumi. Kebanyakan pendapat para sejarawan dan ulama tafsir berpendirian bahhwa sanya manusia pertama diciptakan setelah Jin itu ialah Nabi Adam A.S. Ibnu Katsir berpendapat dalam tafsirnya Tafsir al-Qur'an Al-'Adzim: "awwalu man sakan fi alardi al-Jinnu fa afsadu fii ha", maksud nya bahwa Allah menciptakan manusia dari tanah, dan makhluk pertama yang bersinggah di bumi adalah Jin dan mereka sangat merusak., saling menumpahkan darah, dan saling membutuh satu sama 
lain. ${ }^{2}$ Syekh Muhammad ibn Umar Al-Nawawi mengutip riwayat Dahk dari Ibnu Abbas bahwa setelah Iblis diciptakan dan saling merusah dan bunuh membunuh, maka diutuslah Malaikat untu membumi hanguskan mereka yang durhaka, setelah itu diciptakanlah manusia pertama, yaitu Adam A.S. ${ }^{3}$

Dalam maindset muslim sudah barang tentu Nabi adam a.s disebut bapak manusia, karena dari beliaulah asal keturunan semua manusia, bukanlah manusia itu keturunan dari kera, seperti pendapat orang-orang tertentu. Sebelum nabi adam a.s dijadikan, terlebih dahulu Allah swt menjadikan makhluk bangsa jin dari api yang sangat panas. Di dalam firmannya, Allah Swt menerangkan: "Kami telah menjadikan jin, sebelum manusia, dari api yang sangat panas (Al-Hijr: 27). Pada ayat ini dijelakan bahwa jin adalah ciptaan sebelum manusia.

Namun bagaimana jika ada sebuah pendapat tentang awal penciptaan manusia bukan juga dari Jin dan Iblis, akan tetapi sebelum mereka ada makhluk lain, makhluk yang diberikan ciri memiliki kemiripan dengan manusia? ${ }^{4}$ Setelah mereka membuat kerusakan, lalu Allah membumi hanguskan, dan menggantinya denga yang lebih bagus, yatu Adam A.S dengan diberikan ilmu. Melihat dari penafsiran di atas penulis berasumsi bahwa ada segolongan makhluk yang diyakini pernah meduduki bumi sebelum Nabi Adam A.S dan memiliki kehidupan yang makmur. Penafsiran Ibnu 'Atsur sangat menarik yang sampai pada kesimpulan bahwa nama Al-Hinn dan Al-Binn adalah makhluk yang berakal pertama di bumi.

Jadi penelitian ini mencoba melihat bagaimana metode penafsiran Ibnu 'Atsur terhadap surah al-Baqarah ayat 30 dalam tafsir Al-Tahrir wa Al-Tanwir. Dan untuk lebih fokus, penelitian ini melemparkan beberapa pertanyaan seperti, bagaimana Ibn 'Atsur samapai kepada penafsiran tersebut? Apakah ada keterpengaruhan penafsir terkait ayat itu? Dan apa yang sebenarnya yang terjadi pada masa itu?

\section{Biografi Ibnu 'Atsur}

Ibnu 'Atsur memiliki nama lengkap yaitu Muhammad Thahir Ibn 'Atsur, seorang yang mengkepalai ulama di Tunis. Ia dilahirkan di Tunis tahun $1296 \mathrm{H}$ (1876 M), bermadzhab Maliki. Ia juga merupakan Ahlu Lugoh di Mesir dan seorang cendikian di Damaskus, dan sangat berpengaruh dan berperan penting di

${ }^{2}$ Ibnu Katsir, Tafsir Al-Qur'an Al-'Adzim, juz. 1 (Libanon: Dar Al-Kutub Al-'Ilmiyyah, 1998), hlm. 133.

${ }^{3}$ Muhammad ibn Umar Al-Nawawi, Murâh Labîd li Kasyafi Ma'nâ Qur'an Maj̃̂̀, juz. 1, (Libanon: Dar Al-Kutub Al-'Ilmiyyah, 1997), hlm. 14-15.

${ }^{4} I b n u$ 'Atsur, Al-Tahrir wa Al-Tanwir, juz. 1, (Tunis: Dar Al-Tunisiyyah, 1984), hlm. 399. 
tanah airnya, menjadi Qadi selama \pm 10 tahun, dan memimpin jama'ah pengajian bapak-bapak yang berbana Jama'ah Zaitunah, dan wafat tahun 1393 H (1972 M) di Tunis. ${ }^{5}$

Adapun karya- karya Ibn 'Atsur terbilang sangat banyak, kitab-kitab yang membahas tetang ilmu-ilmu aqidah dan ilmu-ilmu furu'. Namun diantara sekian banyak ada beberapa yng menjadi rujukan banyak ulama dan menjadi populer, diantaranya adalah: ${ }^{6}$

1. Al-Tahrir wa Al-Tanwir

2. Maqasid al-Syari'ah Al-Islami

3. Usul Al-Nizam Al-Ijtima'i fi Al-Islam

4. Al-Waqfu wa 'Atsaruhu fi Al-Islam

5. Usul Al-Insya' wa Al-Khatabah.

\section{Tafsir Al-Tahrir wa Al-Tanwir}

Adapun sumber penafsiran yang disajikan Ibn 'Atsur dalam kitabnya AlTahrir wa Al-Tanwir adalah tafir bi al-Ra'yi, karena menurut Iyazi bahwa dalam tafsir Ibn 'Atsur banyak mengambil istinbat setelah adanya pendiskripsian. Ibn 'Atsur mengatakan dalam pembukaan tafsirnya: "

$$
\text { "تفسير القرآن المجيد، الجامع لمصالح الدنيا والدين، وموثق شديد العرى من الحق المتين، والحاوي لكليات العلوم }
$$

"tafsir al-Qur'an harus mencakup dalam kemaslahatan dunia dan agama (akhirat), dan memilki bukti-bukti yang akurat dan benar, mencakup sains dan menetapkan sebuah istinbat".

Maksudnya, bahwa salah satu cara menafsirkan al-Qur'an itu harus menuju kepada kebaikan dunia dan akhirat, bukan dengan kepentingan semata, dengan cara menyajikan bukti-bukti yang akurat dan mungkin lebih mendekati kepada yang benar, tapi dengan syarat harus mencakup keilmuan juga didalamnya dan menetapkan kesimpulan yang ma'qul, walaupun a tidak juga meningalkan dalam pengutipan dari sumber riwayah. Ini sesuai dengan nama kitabnya sendiri yang bernama Al-tahrir bermakna al-Sadid (keterikatan), dan al-Tanwir bermakna al-

${ }^{5}$ Muhammad Ali Iyazi, Al-Mufassirun Hayatuhum wa Manhajuhum, (Teheran: Wizarat Farhank wa Irsyad Al-'Ilmi, 1384 H), Juz. I, hlm. 359.

${ }^{6}$ Ibid.,

${ }^{7}$ Muhammad Thahir Ibn 'Atsur, Al-Tahrir wa Al-Tanwir, Juz. I, (Tunis: Al-Dar Al-Tunisiyah, 1884), hlm. 5. 
Aqlul al-Jadid (pendangan terbaru). ${ }^{8}$ Dan ketika ingin mengetahui ke I'jaz-an alQur'an menurt Ibn 'Atsur harus dengan menggunakan logika dan penegtahuan. ${ }^{9}$

Adapun metode penafsiran yang ia miliki yaitu dengan metode tahlili, dengan memamaparkan Asbab al-nuzul, qiro'ah-qira'ah yang sahih dan rajih, seprti ketika mendeskripsikan tentang surah dalam al-Qur'an mengutip dari sunnah nabi. Memuji Ar-Razi dan Burhanu al-Dien, bahwa salah satu kitab yang sangat bagus dalam hal munasabah ayat dan surah adalah karya mereka berdua. ${ }^{10}$ Ditambah ternyata Ibn 'Atsur banyak mengutip juga dari tafsir Al-Kasyaf Zamakhsyari, al-Maharrar al-Wajiz Ibn 'Itiyyah, mafatih al-Gaib Ar-Razi, dan Ruhu al-Ma'ani Alusi ketika membahsa tentang sastra dan penjelasan tambahan. ${ }^{11}$

Iyazi sampai pada kesimpulan bahwa tahfsir Al-Tahrir wa Al-Tanwir merupakan tafsir yang bercorak Adabi (sastra) dan Ijtima'i (sosial) dengan selalu memfokuskan dalam pembahasan makna kosakata-kosakata arab, dan ini menurutnya tafsir ini sangat menarik untuk dibahas. ${ }^{12}$

Dengan metode-metode penafsiran yang digunakan Ibn 'Atsur dalam kitab tafsirnya yang sangat menarik karena ini juga merupakan tafsir yang mengarah kepada ilmu pengetahuan yang baru. Maka dari itu peneliti ingin melihat kearah penafsirannya terhadap surah Al-Baqarah (2): 30 tentang keberadaan makhluk sebelum Adam A.S.

\section{Penafsiran Surah Al-baqarah: 30}

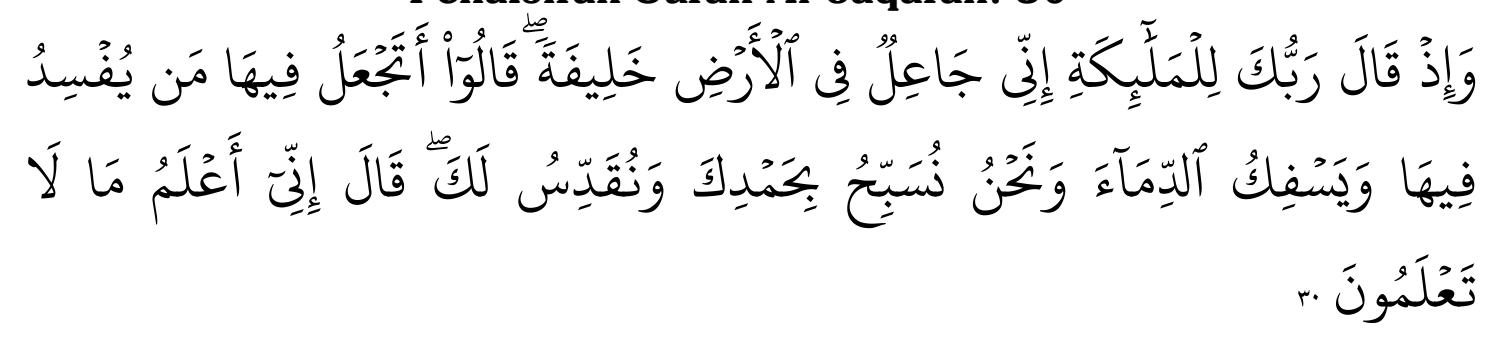

Makna إذ pada ayat diatas merupakan ayat yang menujukkan sebuah kejadian yang telah berlalu, namun memiki pengertian sedang berlangsung tergantung dengan kalimat yang disandarkan kepadanya. ${ }^{13}$ Dialog antara Allah dan

\footnotetext{
${ }^{8}$ Ibid, hlm. 8.

${ }^{9}$ Iyazi, Op.Cit. hlm. 362.

${ }^{10}$ Ibid.,

${ }^{11}$ Ibn 'Atsur, Op.Cit, hlm. 7.

${ }^{12}$ Iyazi, Op.Cit, hlm. 365.

${ }^{13}$ Ibnu 'Atsur, Op. Cit., hlm. 395.
} 
Malaikat tentang penciptaan asal mula makhluk, pengertian dialog disini yaitu sama-sama mendengar tanpa memilki perantaraan penyampai. ${ }^{14}$

Ibn 'Atsur orangnya cukup berani dalam menuliskan penafsiran dalam kitabnya, mengutip pendapat yang aneh didengar orang awam ,namun dia tetap mencoba menuliskannya. Seperti penafsiran kata "ملائكة" berasala dari kata "ملك", adapun ta' al-Ta'nis di akhir kalimat menujukkan bahwan malikat itu merupakan anak (بنات الله) perempuan dari Tuhan, mengutip dari aqidah Nasani. ${ }^{15}$ Jadi selagi itu merupakan pengetahuan yang sudah lumrah, maka tidak ada salahnya dimasukkan di tafsir, agar penjelsannya bisa kaya, dan yang belum tau bisa tau.

Penafsiran "خليفة" memilki arti yaitu seseorang yang memilki hak sebagai utusan pengganti tuhan di bumi dalam menjalani urusan-Nya (فوكله إلي الإنسان). Namun dalam hal ini, bukan berarti Tuhan meninggalkan atau tidak bisa menguru sendiri akan ciptaan-Nya. Tapi memang kehendak Tuhan seperti itu. ${ }^{16}$ Walaupun masih banyak perdebatan panjang bagaimana Khalifah yang sebenarnya dimaksud oleh Allah SWT yang sampai kepada hasil penetapan kelompok-kelompok pendukung Jhalimah dan demokrasi. ${ }^{17}$

Penelitian tahun 2015 dari Rahmat Setiawan, memaparkan hal yang cukup menarik kepada peneliti, bahwa ketika ia mendeskripsikan makna Khalifah dalam surah al-Baqarah (2): 30, ternyata khalifah yang dimaksud ayat tersebut bukan ditujukan kepada nabi Adam A.S, tapi kepada Muhammad S.A.W dengan menerapkan teori hermeneutika Gadamer. ${ }^{18}$ Dengan mangaitkan kepada ranah Ibadah dan sosial yang mana keduanya harus selalu beriringan, tanpa tanpa ketimpangan.

Namun, berbeda dengan Ibnu 'Atsur memaknakan khalifah yang dimaksud dalam ayat apabila benar bahwa zaman dahulu telah ada makhluk yang makmur di bumi satu golongan yang bernama Al-Hinnu dan Al-Binnu. ${ }^{19}$ Namun ada sebuah pernyataan tentang awal penciptaan manusia bukan dari golongan Jin atau

${ }^{14}$ Ibid.,

${ }^{15}$ Ibnu 'Atsur, Op.Cit., hlm. 397.

${ }^{16}$ Ibid, hlm. 398-399.

${ }^{17}$ Lihat catatan HTI dan UUD RI tentang seorang pemimpin yang layak untuk menjadi pemimpin. Karena untuk menjadi seorang pemimpin memilki ketentuan-ketentuan yang harus bisa dipenuhi untuk para calon.

${ }^{18}$ Rahmat Setiawan, Makna Khalifah dan 'Abid sebagai Destinasi Manusia di Bumi, (Jurnal DIDAKTIKA ISLAMIKA, Vol. VI, No. II, 2015), hlm. 89.

${ }^{19} \mathrm{Ibnu}$ 'Atsur, Op.Cit, hlm. 398. 
Iblis, namun sebelum mereka ada makhluk lain, makhluk yang diberikan ciri memiliki kemiripan dengan manusia, dikutip dari Ibnu 'Atsur dalam tafsir Al-Tahrir wal Al-Tanwir.

“أن يراد من الحليفة معناه الحقيقي إذا صح أن الأرض كانت معمورة من قبلُ بطائفة من المخلوقات يسمَّون الحِن والبِن بحاء مهملة

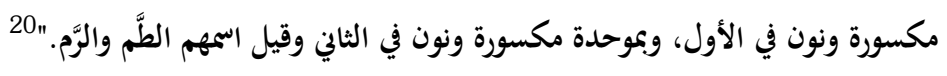

Makna yang bisa ambil adalah bahwa ada makluk segolongan makhluk yang diyakini pernah meduduki bumi sebelum Nabi Adam A.S dan memiliki kehidupan yang makmur. Penafsiran Ibnu 'Atsur sangat menarik yang sampai pada kesimpulan bahwa nama Al-Hinn dan Al-Binn adalah makhluk pertama di bumi.

Jika selama ini kita hanya tahu bahwa manusia makhluk sejenis manusia yang pertama diciptakan ialah nabi Adam A.S, ini keliru. ${ }^{21}$ Bahasa sederhana manusia dalam meyebutkan itu adalah Al-Hayyan Ibn Bayyan artinya seseorang yang tidak diketahui pasti akan keberadaannya. Ibn 'Atsur ternyata tentang hal ini mengutip perkataan atau keyakinan bangsa Persia dan Yunani. Persia yakin bahwa ada segolongan makhluk sebelum manusia di bumi yang bernama al-Tammu dan al-Rammu, sedangkan Yunani meyakini bahwa dulu bumi sangat makmur dengan adanya makhluk yang bernama al-Titan, dipeihara para pembesar pendeta guna untuk bisa merusak dunia. ${ }^{22}$

Penulis mencoba membandingkan dengan mufassir dengan Ibnu 'Atsur dan Muhammad Abduh dalam tafsirnya Al-Manar, karena diketahui mreka berdua satu masa. Muhammad Abduh menetapkan bahwa bukan nabi Adam A.S yang menjadi manusia pertama di bumi yang diciptakan memilki akal.

قال الأستاذ: فليس آدم أول الصنف من الحيوان علي هذه الأرض، وإنما كان أول طائفة جديدة من الحيوان الناطق.23

Tapi mereka dari golongan yang memilki fisik dan bertutur, tapi tidak semua berkelakuan baik. Tafsiran ini mengutarakan tentang hidupnya makhluk sebelum Adam, dan diciptakan Adam A.S hanya untuk pembaharuan yang lebih baik dan selalu mengutip dari cerita persia dan runtuhnya.

Menariknya menurut Abduh: ternyata al-Hinn adalah manusia sebelum Adam A.S, dan al-Binn adalah makhluk halus sebelum Jin. ${ }^{24}$ Mereka semua

\footnotetext{
${ }^{20}$ Ibid, hlm. 399.

${ }^{21}$ Lihat tafsir Al-Tahrir wa Al-Tanwir dan Tafsir Al-Manar pada surah al-Baqarah (2): 30

${ }^{22}$ Ibid, hlm. 399.

${ }^{23}$ Muhammad Abduh, Tafsir Al-Manar, Cet. II, (Kairo: Dar Al-Manar, 1947), Juz. I, hlm.
} 258.

${ }^{24}$ Ibid., 
menjadi perusak di bumi sampai Allah membumi hanguskan dengan tentaranya dari golongan Malaikat dan Jin terbaru. ${ }^{25}$ Oleh karena itu "Mã qulnã hu man Ãdama laisa awaalu al-ãqilati allafi sakanat al-Ardi" ${ }^{26}$ Dalam hal ini ternyata kita bisa lebih banyak tau bahwa telah hidup mahkluk yang diciptakan Tuhan di Bumi sebelum makhluk yang sudah biasa kita ketahui bersama.

Sebagian peneliti mencoba melihat asa-usul mulainya kehidupan di bumi dengan berbagai teori yang digunakan guna mengukur sudah berapa manusi tinggal. Donald R. Wilson berpandangan mengukur usia manusia bisa dilakukan dengan menggunakan alat, seperti Alat atau perkakas adalah salah satu ciri manusia, jika ini merupakan sebuah ciri-ciri adanya kehidupan manusia, maka bisa ditetapkan sekitar 500.000-2.000.000 tahun yang lalu. ${ }^{27}$

Pernyatan-pernyataan dari penafsir di atas menimbulkan banyak pertanyaan, apakah pernyataan itu benar adanya? Apakah itu yang sesungguhnya ? apakah ada yang mempengaruhi sang penafsir ? untuk diketahui lebih lanjut, maka dilakukanlah analisis untuk memperdalam maksud.

\section{Analis Isi}

Dari pemaparan di atas banyak point yang bisa diambil, diantaranya adalah:

1. Bahwa Ibn 'Atsur menginginkan tafsir yang memiliki sifat keilmuan, bukan yang hanya mengutip-mengutip rawi saja, tanpa memilki pandangan yang baru.

Pendapat bisa dilihat ketika pembukaan tafsirnya yang mengkrtik banyak tafsir dan menggolongkan beberapa tafsir yang menurut dia bagus. ${ }^{28}$ Jika ada tafsir yag tidak memberikan pengetahuan akan ilmu, maka itu hanya sebuah plagiat (COPAS).

2. Masalah menafsirkan surah al-Baqarah (2): 30, Ibn 'Atsur menyebutkan bahwa ada sebagian pendapat yang mengatakan bahwa makhluk pertama di tinggal di bumi ini bukanlah Nabi Adam A.S dari golongan manusia, begitu juga dengan Jin. Tapi disini Ibn 'Atsur megatakan dalam tafsirnya makhluk pertama yang diciptakan di Bumi bernama Al-Hinn dan Al-Binn, memilki sifat seperti manusia, yaitu ingin makan dan berdarah-darah.

${ }^{25} \mathrm{Ibid}$.

${ }^{26}$ Ibid.,

${ }^{27}$ Donald R. Wilson, How Early Is Man? Christianity Today, 14 September 1962, hlm. $27-$ 28.

${ }^{28}$ Kata "Bagus" disini ialah bahwa ketika mufassir ingin mendiskripsikan sesuatu, maka selain ia mengutip riwayat, harus juga memberi masukan yang baru juga, walaupun itu dari sumber manapun, karena demikian juga merupakan sebuah ilmu pengetahuan. Ibnu 'Atsur (halaman. 7-8) 
Tapi dalam penafsiran ini Ibn 'Atsur tidak terlalu bersikeras untuk memaksa pembaca yakin dengan pernyataan tersebut, terlihat dari pendiskripsiannya tidak terlalu mendalam sekali. Menurut penulis ini bukanlah sebuah masalah dalam penafsiran ketika memasukkan keyakinan-keyakinan dari sahabat kita dari nonMuslim. Yakin penulis ini murni pengetahuan untuk para pembaca, guna pengetahuannya lebih luas. Sebagaimana yang ditulis oleh Abdul Majid, Dkk dalam buku yang berjudul Mukjizat Al-Qur'an dan Sunnah tentang IPTEK: bahwa kemukjizatan al-Qur'an itu bisa diketahui oleh pakar ilmu pengetahuan sesuai dengan disiplin ilmu pengetahuannya, ketika mereka melihat dari susanan kalimat, dan pemberitahuan dari umat masa lalu, kejadian mendatang, hukum syari'at dan lain sebagainya. ${ }^{29}$ Menunjukkan bahwa layaknya seorang pakar untuk berasumsi dalam pendapatnya yang usdah diyakini bersama bahwa dia benar seorang pakar.

3. Ini adanya sebuah keterpengaruhan dengan ditemukannya sebuah rangka berusia 26.000. Pada tahun 1823, seorang profesor Geologi di University Oxford, Inggris, menemukan dan menetapkan bahwa adanya sebuah penemuan The Red lady rangka yang diperkirakan berusia kira-kira 18.000 di sebuah gua di Goat's Hole Cave di Pavillon, Gower, Wales. Dengan penelitian yang lebih lanjut sampai pada penetapan bahwa rangka yang ditemukan berusia 26.000 tahun. ${ }^{30}$ Asusmsi penulis melihat penemuan dengan kelahiran Ibn 'Atsur satu abad yang sama, bisa jadi penemuan ini dimasukkan oleh Ibn 'Atsur dalam tafsirnya, dalam artian bahwa la tidak mengenyampingkan penemuan tersebut tapi diapresiasi.

4. Yang dimaksudkan dengan manusia pertama sebelum Adam A.S yang berakal, mungkin yang dimaksud adalah Pichecantropus Erectus memiliki volume otak seperti manusia, namun tidak begitu normal jika dibandingkan dengan manusia. ${ }^{31}$ Yang mana dari Homo Erectus akan terus berevolusi menjadi menjadi memilki peradaban sesaat, karena memilki otak lebih besar dari pada kera, jadi membuat mereka bisa berfikir. Sepertinya Muhammad Abdul beranjak dari sini yang sampai kepada kesimpulan, adanya makhluk yang berakal sebelum Adam A.S.

\footnotetext{
${ }^{29}$ Abdul Majid, dkk, Mukjizat Al-Qur'an dan Sunnah tentang IPTEK,Jilid. II, (Jakarta: Gema Insani Press, 1997), hlm. 27.

${ }^{30} \mathrm{https} / / / \mathrm{m} . k a s k u s . c o . i d / n a b i-a d a m-a s-b u k a n-m a k h l u k-p e r t a m a-d i b u m i, \quad$ diakses 26 Mei 2018, dan https://en.m.wikipedia.orgkwiki/Red-Lady-of-Pavilland, diakses 26 Mei 2018

31 J. F. O'Connel, dkk, Grandmothering and the evolution of Homo Erectus, (Jurnal Of Human Evolution, Academic Press, 1999), hlm. 468-469.
} 
5. Melihat juga bahwa Ibn 'Atsur banyak mengutip pendapat Israiliyyah, jadi tidak mengherankan lagi apabila ia menguti keyakinan-keyakinan dari cerita orang Persia dn Yunani dalam ayat tersebut.

\section{Kesimpulan}

Dalam metode penafsiran, Ibn 'Atsur memakai sumber penafsiran bi al-'Aqli degan lebih mengutamakan sisi-sisi keilmuan dalama tafsirnya, karena ia yakin bahwa jika hanya mengutip atau mengumpulkan karya-karta tafsir dan mejadikan buku tafsir baru, ini bukanlah tafsir yang bagus, tapi harus ada masukan-masukan yang baru/ yang ilmiyah terhadapnya. Jenis penafsiran yang digunakan adalan Tahlili, dengan memunculkan sebab-sebab turunnya ayat, membahas masalah bahaa, qiraat, dan Qaul yang sehat, dan ditambah dengan Munsabah ayat dan surat yang kuat, menjadikan tafsir Al-tahrir wa Al-Tanwir menjadi tafsir yang bernilai tinggi. Apalagi disandingkan dengan corak tafsir Al-'Ilmi, tafsir yang mementingkan masalah keilmuan, bukan hanya mengutip-ngutip perkataanperkataan, tapi menyajikan banyak pengetahuan-pengetahuan yang ia anggap itu pantas dimasukkan ke dalam tafsirnya dan perlu diketahui pembaca.

Dari penjelasan di atas bisa di ambil kesimpulan bahwa, ketika sebuah pengetahuan itu penting untuk dimunculkan, maka itu harus dimunculkan. Jika orang lain sebagai jurnalis, maka ia harus menulis apa yang ia dapatkan dari rekmana atau wawancaranya itu. Begitulah yang dilakukan mufassir Ibn 'Atsur dan mufassiri Muhammad Abduh, ketika mereka mengethaui bahwa adanya sebuah temuan tentang kerangka manusia yang dianggap ciptaan pertama sebelum Adam A.S mereka harus mengutipnya dam memasukkannya ke dalam tafsir, karena mereka mengggap ini adalah ilmu pengetahuan. Bairpun tidak semua yang dianngap temuan itu benar, tanpa menyaring terlebih dahulu. Tapi disini Ibn 'Atsur berkata pada tafsirnya, tapi tidak seolah-seolah memang pendapat tersebut yang benar, tidak demikian. Tapi ia hanya memberikan pandanga lain, guna keluaaan ilmu pengetahuan dan sejarah.

\section{Referensi}

Abduh, Muhammad, Tafsir Al-Manar, Kairo: Dar Al-Manar. 1947.

Abdul Majid, dkk. Mukjizat Al-Qur'an dan Sunnah tentang IPTEK, Jakarta: Gema Insani Press. 1997.

Al-Nawawi, Muhammad ibn Umar, Murâh Labîd li Kasyafi Ma'nâ Qur'an Majî̀. Libanon: Dar Al-Kutub Al-'Ilmiyyah. 1997. 
Ibn 'Atsur, Muhammad Thahir, Al-Tahrir wa Al-Tanwir, Tunis: Al-Dar Al-Tunisiyah. 1884.

Ibnu 'Atsur, Al-Tahrir wa Al-Tanwir, Tunis: Dar Al-Tunisiyyah, 1984.

Ibnu Katsir, Tafsir Al-Qur'an Al-'Adzim, Libanon: Dar Al-Kutub Al 'Ilmiyyah, 1998.

Iyazi, Muhammad Ali, Al-Mufassirun Hayatuhum wa Manhajuhum, Teheran: Wizarat Farhank wa Irsyad Al-'Ilmi, $1384 \mathrm{H}$.

J. F. O'Connel, dkk, Grandmothering and the evolution of Homo Erectus, Jurnal Of Human Evolution. Academic Press, 1999.

R. Wilson, Donald, How Early Is Man? Christianity Today, 1962.

Setiawan, Rahmat, Makna Khalifah dan 'Abid sebagai Destinasi Manusia di Bumi. Jurnal DIDAKTIKA ISLAMIKA. 2015

https://en.m.wikipedia.orgkwiki/Red-Lady-of-Pavilland, diakses 26 Mei 2018

https://m.kaskus.co.id/nabi-adam-as-bukan-makhluk-pertama-dibumi 